\title{
About the editors
}

Nicolas Papadopoulos is Distinguished Research Professor of Marketing and International Business at the Sprott School of Business of Carleton University in Ottawa, Canada, where he has served as Director, Associate Dean (Research), IB Teaching Area Coordinator, Director of the IB Study Group, and Chancellor's Professor.

He worked with Exxon, $3 \mathrm{M}$, and $\mathrm{P} \& \mathrm{G}$ before turning to his academic career, and has maintained close ties with the business community through consulting, executive training, and other engagements. In research, Nicolas is known worldwide as a leading scholar in country and place images, country and place branding, and international market selection. He has over 340 publications, including 15 books and more than 90 journal articles and book chapters, and has given invited keynote addresses at such events as the Multicultural Marketing Conference (Mexico), 9th Congress of the Società Italiana di Marketing (Italy), Export Summit IV (Greece), and Consumer Research Summit on Place \& Identity (UK), as well as well over 100 other presentations and seminars.

His research has been covered extensively in interviews and feature stories internationally, ranging from The Strategist in India to La Reforma (Mexico) and The Economist (UK), and has been recognized through numerous honours and distinctions. He has received the Capital Educators Award from the Ottawa Centre for Research and Innovation; Carleton University's Davidson Dunton Lectureship Award, Graduate Mentorship Award, and two Research Achievement Awards; the Outstanding Service or Best Reviewer awards from various journals; and 10 best paper awards, including most recently the 2019 Best Paper Award in International Business of the Administrative Sciences Association of Canada. He is an Honorary International Member of the Società Italiana di Marketing, and is currently serving on the Senior Advisory Board of International Marketing Review and the Journal of Product and Brand Management (UK), on the Editorial Review Boards of the Journal of International Business Studies, Journal of International Marketing (US), and five other journals, and as Associate Editor (IB) of the Canadian Journal of Administrative Sciences.

Mark Cleveland is a Western Faculty Scholar and the Dancap Private Equity Chair in Consumer Behavior at the DAN Department of Management and 
Organizational Studies of the University of Western Ontario in London, Canada. He is a former Director of Western's Collaborative Graduate Program in Migration and Ethnic Relations. As the coordinator of the Consumer Behavior area, he teaches numerous courses at graduate and undergraduate levels. Since 2013, Dr Cleveland has been an Associate Editor for the journal International Marketing Review. He is on the editorial board of several other journals, and he has served as a Guest Co-editor for several journals as well as Track Chair for numerous conferences.

His research interests are interdisciplinary, spanning marketing, consumer behavior, social psychology, and international business, with a special focus on globalization, identity and culture; cross-cultural consumer behavior; cosmopolitanism, xenocentrism, materialism, and consumer ethnocentrism; international market segmentation, promotion, and branding; sustainability and green marketing; and psychometrics. To date, he has conducted research on consumers living in 22 countries. He has authored, co-authored, or edited more than 100 publications, including 43 journal articles, 3 book chapters, a book on global consumer culture, and 51 conference papers. He has presented his research at conferences spanning five continents.

His scholarly work has more than 5000 citations on Google Scholar, and his research has been featured in prominent media outlets including The New York Times, The Globe and Mail, Psychology Today, and CBC's Marketplace. Mark has been a consultant for numerous organizations, including McKinsey \& Company, McCann Worldgroup, and Industry Canada. He has received many awards for his scholarly activities, including three best paper awards, Western's Faculty Scholar Award, and the Hans B. Thorelli Award, from the American Marketing Association, for an article that has made the most significant and long-term contribution to international marketing theory or practice. 